\title{
Morphometric measurement, relative abundance and effect of physico-chemical parameters of water on ichthyofaunistic diversity of River Tochi District North Waziristan (Newly Merged District), Khyber Pakhtunkhwa
}

\author{
Hafiz Jamil Ur Rehman ${ }^{1}$, Muhammad Nasir Khabir ${ }^{2 *}$, Amir Sohail \\ Khan $^{2}$, Zaigham Hassan ${ }^{2}$, Ibrar Khan ${ }^{3}$ and Mohsin Kamal Khan ${ }^{4}$ \\ 1. Department of Zoology, University of Science and Technology, Bannu-Pakistan \\ 2. Department of Zoology, University of Peshawar, Peshawar-Pakistan \\ 3. Department of Zoology, Hazara University, Mansehra-Pakistan \\ 4. Department of Biological Sciences, Gomal University Dera Ismail Khan-Pakistan \\ *Corresponding author's email: Nasirkhabir7@gmail.com
}

Citation

Hafiz Jamil Ur Rehman, Muhammad Nasir Khabir, Amir Sohail Khan, Zaigham Hassan, Ibrar Khan and Mohsin Kamal Khan. Morphometric measurement, relative abundance and effect of physico-chemical parameters of water on ichthyofaunistic diversity of River Tochi District North Waziristan (Newly Merged District), Khyber Pakhtunkhwa. Pure and Applied Biology. Vol. 9, Issue 1, pp501-506. http://dx.doi.org/10.19045/bspab.2020.90055

\begin{tabular}{llll}
\hline Received: 16/08/2019 & Revised: 06/11/2019 & Accepted: 12/11/2019 & Online First: 05/12/2019 \\
\hline
\end{tabular}

\section{Abstract}

An ichthyofaunistic survey of River Tochi at District North Waziristan (NW) was conducted from July 2018 to December 2018 to know about morphometric measurement and relative abundance of fish fauna and impact of physico-chemical parameters on fish biodiversity and survival. A total 604 specimens were collected containing 21 species. The total reported species of fishes belong to five different orders (Cypriniformes, Channiformes, Siluriformes, Perciformes and Mastacembeliformes), seven families (Cyprinidae, Nemacheilidae, Channidae, Siluridae, Sisoridae Cichilidae and Mastacembelidae) and nine genera (Barilius, Gara, Aspidoparia, Crossochielus, Cyprinion, Cyprinus, Puntius, Cirrihinus, Labeo, Schistura, Channa, Ompok, Glypthorax, Oreochromis and Mastacembelis). Family Cyprinidae was the dominant family of the all reported families. Species Schistura affaciata is the first time report of this species from Khyber Pakhtunkhwa. Analytical results of Water quality parameters like Temperature, $\mathrm{pH}$, Conductivity, Alkalinity, Salinity, Total Dissolved Solids (TDS), Total Suspended Solids (TSS), Total Hardness, Magnesium (Mg) Hardness, Calcium (Ca) Hardness and free $\mathrm{CO}_{2}$ reveal that all the values fall in standard range for fish life.

Keywords: Cyprinidae; Fish fauna; Physico-chemical; River Tochi; Water quality

\section{Introduction}

Fishes makes about half of the total recognised species of vertebrates [1, 2]. Every year, few hundred species are added to the list of fish diversity [3]. In Pakistan, there found about 200 fish species in all freshwater bodies of the country [4-6]. Ichthyodiversiy usually depends on different living and non living components 
of ecosystem i-e depth of water body, changeability in water level and morphometric topographies. Fisheries output also influenced by hydro biological structures of catch point [7]. The limnological properties and physical conditions of water body affect the species composition of water body [8]. The sustainability of fish diversity and its abundance is based on the hydrological parameters as well as plankton diversity [9]. This study was aimed to determine ichthyofaunal diversity, analysis of physicchemical parameter of water of river tochi and their effect on fish fauna. All the proposed aims were achieved successfully. This study was carried out District North Waziristan which is second largest district in newly merged districts of Khyber Pakhtunkhwa. The North Waziristan Agency (NWA) was set up in 1895. It was in the year, 1910 when N.W. A. was constituted as a full-fledged agency with its Headquarter "Miran Shah" [10]. This N. W. A. become a district of Khyber pakhtonkhwa in May, 2018. The River Tochi also called as Gambila River, is located in Khyber Pakhtunkhwa province. It is an important River of district North Waziristan and it is formed by the conjunction of "Margha" and "Masthoni" streams. Both streams come from the northern side of Vargin, Paktia (Afghanistan) and meet at "Dwathoi" district North Waziristan, Pakistan. In the hills and within the limits of district North Waziristan and Bannu district, the River is called as "Tochi" but once it enters Marwat region, it is called "Gambilla" [11]. The total length of River Tochi from origin to end is approximately $373 \mathrm{~km}$ [12].

\section{Materials and methods}

Different sites were chosen for water sampling and fish collection. Water sampling and fish collection was done from July, 2018 to December, 2018.

During whole study period, different types of fish gears were used for collection of fish. A month wise visit was arranged for the collection of the fish in the river. For preservation, $10 \%$ formalin solution was used. The large sized specimens of the fish were injected with pure formalin to avoid rotting. The list of the keys used in the identification of the fish is as under;

1. Fauna of Lahore [13]

2. Fishes of Punjab, Pakistan [14]

3. Cat fishes of India [15]

4. Freshwater fishes of the Indian region [16].

For studying different physical and chemical characteristics of the water of the river Tochi, water samples were also collected from each collection point during collection trip using standard protocol. All collected water samples were studied for different physical and chemical properties of water like $\mathrm{pH}$, conductivity, salinity, total dissolved substance, total alkalinity, Total hardness, Ca hardness, Mg hardness, total suspended solid, Free $\mathrm{CO}_{2}$, Air and water temperature.

\section{Results}

\section{Ichthfaunistic diversity of river Tochi}

During the six months study period from July to December 2018, the ichthyofaunistic composition of the River tochi district North Waziristan has been explored. A total of 604 specimens fishes were collected which comprised of 21 fish species. The total reported fish species of the study were belonged to 5 orders, 7 families and 9 different genera. The reported species were Barilius modestus, Barilius naseeri, Barilius vagra, Barilius pakistanicus, Gara gotyla, Aspidoparia morar, Crossocheilus diplocheilus, Cyprinion watsoni, Cyprinus carpio, Puntius conchonius, Puntius sophore, Cirrhinus mrigala, Labeo rohita, Schistura curtistigma, Schistura prashari, Schistura afaciata. Channa gachua, Ompok pabda, Glyptothorax naziri, Oreochromis niloticus and Mastacembelus armatus. All the reported species with their taxonomic position is given in the following table 1 .

\section{Relative abundance of fish fauna}

In order to determine relative abundance of fish fauna of river tochi, fish catch trip was arranged in each month from July to December, 2018. The following table 2 and fig. 1 show the month wise catch of number of specimens of all reported species. 
Table 1. Reported fish species from river Tochi

\begin{tabular}{|c|c|c|c|c|}
\hline S. No & Order & Family & Genus & Genus and Species \\
\hline 1 & \multirow{16}{*}{ Cypriniformes } & \multirow{13}{*}{ Cyprinidae } & \multirow{4}{*}{ Barilius } & Barilius modestus \\
\hline 2 & & & & Barilius naseeri \\
\hline 3 & & & & Barilius vagra \\
\hline 4 & & & & Barilius pakistanicus \\
\hline 5 & & & Gara & Gara gotyla \\
\hline 6 & & & Aspidoparia & Aspidoparia morar \\
\hline 7 & & & Crossocheilus & Crossocheilus diplocheilus \\
\hline 8 & & & Cyprinion & Cyprinion watsoni \\
\hline 9 & & & Cyprinus & Cyprinus carpio \\
\hline 10 & & & \multirow{2}{*}{ Puntius } & Puntius conchonius \\
\hline 11 & & & & Puntius sophore \\
\hline 12 & & & Cirrihunus & Cirrhinus mrigala \\
\hline 13 & & & Labeo & Labeo rohita \\
\hline 14 & & \multirow{3}{*}{ Nemacheilidae } & \multirow{3}{*}{ Schistura } & Schistura curtistigma \\
\hline 15 & & & & Schistura prashari \\
\hline 16 & & & & Schistura afaciata \\
\hline 17 & Channiformes & Channidae & Channa & Channa gachua \\
\hline 18 & Siluriformes & Siluridae & Ompok & Ompok pabda \\
\hline 19 & & Sisoridae & Glyptothorax & Glyptothorax naziri \\
\hline 20 & Perciformes & Cichilidae & Oreochromis & Oreochromis niloticus \\
\hline 21 & Mastacembeliformes & Mastacembelidae & Matacembelus & Mastacembelus armatus \\
\hline
\end{tabular}

Table 2. Month wise relative abundance of fish fauna

\begin{tabular}{|c|c|c|c|c|c|c|c|c|c|}
\hline S. No. & Fish Species & July & Aug & Sep & Oct & Nov & Dec & Tot & $\begin{array}{c}\text { Catch } \\
(\%)\end{array}$ \\
\hline 1 & Barilius naseeri & $\mathbf{4}$ & $\mathbf{6}$ & $\mathbf{2}$ & $\mathbf{3}$ & $\mathbf{4}$ & $\mathbf{8}$ & 27 & 4.5 \\
\hline 2 & B. modestus & $\mathbf{5}$ & $\mathbf{2}$ & $\mathbf{4}$ & $\mathbf{5}$ & $\mathbf{2}$ & $\mathbf{4}$ & 22 & 3.6 \\
\hline 3 & B. vagra & $\mathbf{7}$ & $\mathbf{1 1}$ & $\mathbf{3}$ & $\mathbf{1 0}$ & $\mathbf{1 4}$ & $\mathbf{1 6}$ & 61 & 10.1 \\
\hline 4 & B. pakistanicus & $\mathbf{5}$ & $\mathbf{9}$ & $\mathbf{4}$ & $\mathbf{8}$ & $\mathbf{6}$ & $\mathbf{5}$ & 37 & 6.1 \\
\hline 5 & Gara gotyla & $\mathbf{2}$ & $\mathbf{5}$ & $\mathbf{2}$ & $\mathbf{3}$ & $\mathbf{6}$ & $\mathbf{4}$ & 22 & 3.6 \\
\hline 6 & Aspidoparia morar & $\mathbf{9}$ & $\mathbf{1 8}$ & $\mathbf{3 0}$ & $\mathbf{2 0}$ & $\mathbf{4 0}$ & $\mathbf{2 5}$ & 142 & 23.5 \\
\hline 7 & Crossocheilus diplocheilus & $\mathbf{2}$ & $\mathbf{6}$ & $\mathbf{5}$ & $\mathbf{4}$ & $\mathbf{1}$ & $\mathbf{1}$ & 19 & 3.1 \\
\hline 8 & Cyprinion watsoni & $\mathbf{2}$ & $\mathbf{1}$ & $\mathbf{0}$ & $\mathbf{2}$ & $\mathbf{0}$ & $\mathbf{0}$ & 5 & 0.8 \\
\hline 9 & Cyprinus carpio & $\mathbf{2}$ & $\mathbf{4}$ & $\mathbf{7}$ & $\mathbf{6}$ & $\mathbf{7}$ & $\mathbf{5}$ & 31 & 5.1 \\
\hline 10 & P. sophore & $\mathbf{4}$ & $\mathbf{8}$ & $\mathbf{1 0}$ & $\mathbf{9}$ & $\mathbf{5}$ & $\mathbf{7}$ & 43 & 7.1 \\
\hline 11 & P. conchonius & $\mathbf{6}$ & $\mathbf{1}$ & $\mathbf{3}$ & $\mathbf{5}$ & $\mathbf{4}$ & $\mathbf{6}$ & 25 & 4.1 \\
\hline 15 & Labeo rohita & $\mathbf{2}$ & $\mathbf{3}$ & $\mathbf{1}$ & $\mathbf{3}$ & $\mathbf{5}$ & $\mathbf{4}$ & 18 & 3.0 \\
\hline 17 & Cirrhinus mrigala & $\mathbf{2}$ & $\mathbf{1}$ & $\mathbf{2}$ & $\mathbf{3}$ & $\mathbf{2}$ & $\mathbf{2}$ & 12 & 2.0 \\
\hline 12 & Schistura curtistigma & $\mathbf{6}$ & $\mathbf{7}$ & $\mathbf{8}$ & $\mathbf{3}$ & $\mathbf{2}$ & $\mathbf{1}$ & 27 & 4.5 \\
\hline 13 & Schistura prashari & $\mathbf{2}$ & $\mathbf{2}$ & $\mathbf{3}$ & $\mathbf{4}$ & $\mathbf{2}$ & $\mathbf{8}$ & 21 & 3.5 \\
\hline 14 & Schistura affaciata & $\mathbf{6}$ & $\mathbf{5}$ & $\mathbf{3}$ & $\mathbf{1}$ & $\mathbf{8}$ & $\mathbf{0}$ & 23 & 3.8 \\
\hline 19 & Channa gachua & $\mathbf{2}$ & $\mathbf{3}$ & $\mathbf{0}$ & $\mathbf{2}$ & $\mathbf{1}$ & $\mathbf{3}$ & 11 & 1.8 \\
\hline 16 & Ompok pabda & $\mathbf{2}$ & $\mathbf{4}$ & $\mathbf{0}$ & $\mathbf{3}$ & $\mathbf{2}$ & $\mathbf{4}$ & 15 & 2.5 \\
\hline 18 & Glyptothorax naziri & $\mathbf{2}$ & $\mathbf{2}$ & $\mathbf{2}$ & $\mathbf{5}$ & $\mathbf{1}$ & $\mathbf{2}$ & 14 & 2.3 \\
\hline 20 & Oreochromis niloticus & $\mathbf{1}$ & $\mathbf{4}$ & $\mathbf{0}$ & $\mathbf{5}$ & $\mathbf{4}$ & $\mathbf{2}$ & 16 & 2.6 \\
\hline 21 & Mastacembelus armatus & $\mathbf{2}$ & $\mathbf{4}$ & $\mathbf{1}$ & $\mathbf{2}$ & $\mathbf{1}$ & $\mathbf{3}$ & 13 & 2.1 \\
\hline & Total & $\mathbf{7 5}$ & $\mathbf{1 0 6}$ & $\mathbf{9 0}$ & $\mathbf{1 0 6}$ & $\mathbf{1 1 7}$ & $\mathbf{1 1 0}$ & 604 & ------ \\
\hline
\end{tabular}




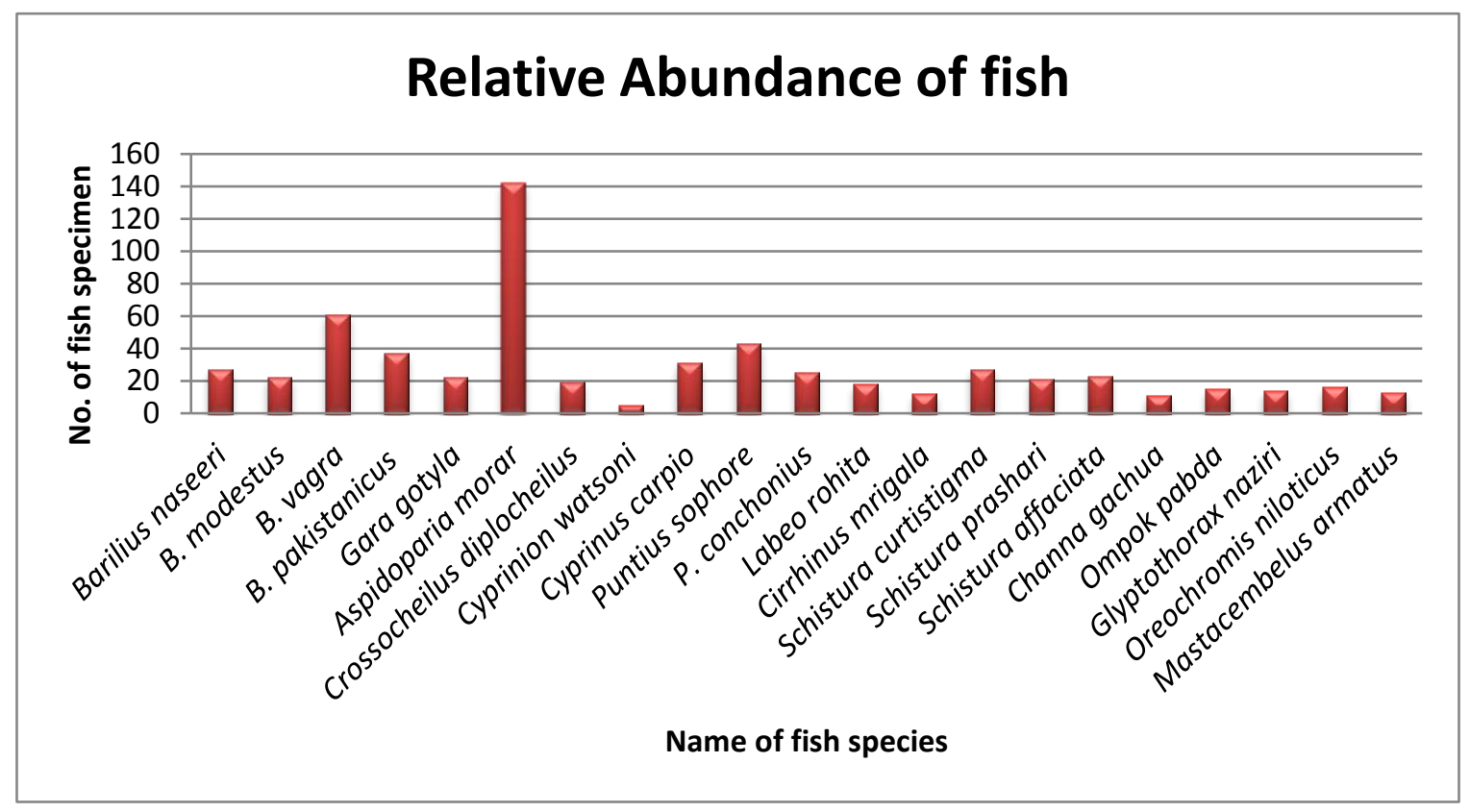

Figure 1. Relative abundance of fish species Morpho-metric measurement of reported fish species

Morpho-metric measurement of at least three specimens of each species was taken each

month and the average was taken as final measurement. The following table 3 shows the average morpho-metric measurement of all reported species.

Table 3. Average morpho-metric measurement of collected fish specimens

\begin{tabular}{|c|c|c|c|c|c|c|c|c|c|}
\hline $\begin{array}{c}\text { S. } \\
\text { No }\end{array}$ & Fish Species & T.L & S.L & F.L & P.O.L & H.D & E.D & B.D & B.W \\
\hline 01 & Barilius naseeri & 7.3 & 5.7 & 6.7 & 6.3 & 1.4 & 0.2 & 1.1 & 0.8 \\
\hline 02 & B. modestus & 8.4 & 5.9 & 6.9 & 6.4 & 1.4 & 0.3 & 1.5 & 0.8 \\
\hline 03 & B. vagra & 8.4 & 6.4 & 7.2 & 6.8 & 1.7 & 0.4 & 1.1 & 0.7 \\
\hline 04 & B. pakistanicus & 8 & 6.3 & 7 & 5.4 & 1.7 & 0.4 & 1.7 & 0.8 \\
\hline 05 & Gara gotyla & 15.1 & 10.9 & 12.7 & 8.9 & 2.7 & 0.4 & 2.1 & 1.9 \\
\hline 06 & Aspidoparia morar & 11.7 & 9.3 & 10.2 & 8.2 & 2.0 & 0.4 & 1.6 & 1.1 \\
\hline 07 & Crossocheilus diplocheilus & 14.3 & 11.5 & 12.7 & 9.6 & 2.2 & 0.3 & 2.6 & 2.4 \\
\hline 08 & Cyprinion watsoni & 12.5 & 9.6 & 10.5 & 8.1 & 1.9 & 0.3 & 2.3 & 2.1 \\
\hline 09 & Cyprinus carpio & 19.2 & 15.6 & 17.9 & 16.2 & 3.3 & 0.5 & 2.9 & 2.4 \\
\hline 10 & Puntius sophore & 8.9 & 6.8 & 7.8 & 5.9 & 1.7 & 0.3 & 2.3 & 1.0 \\
\hline 11 & Puntius conchonius & 8.1 & 6.7 & 7.3 & 5.7 & 1.2 & 0.4 & 1.7 & 0.9 \\
\hline 12 & Labeo rohita & 19.2 & 15.6 & 17.6 & 14.4 & 4.1 & 0.5 & 3.0 & 1.6 \\
\hline 13 & Cirrhinus mrigala & 13.2 & 10.8 & 12.4 & 11.2 & 2.4 & 0.4 & 2.1 & 1.3 \\
\hline 14 & Schistura curstigma & 4.6 & 3.9 & 4.2 & 3.1 & 0.9 & 0.1 & 0.5 & 0.6 \\
\hline 15 & S. prashari & 4.5 & 3.8 & 4.3 & 3.1 & 0.8 & 0.1 & 0.6 & 0.6 \\
\hline 16 & S. affaciata & 4.7 & 3.9 & 4.2 & 3.2 & 0.9 & 0.1 & 0.5 & 0.5 \\
\hline 17 & Channa gachua & 9.3 & 7.8 & - & 8.1 & 1.6 & 0.5 & 1.1 & 0.9 \\
\hline 18 & Ompok pabda & 15.8 & 13.4 & 14.5 & 14.2 & 3.2 & 0.5 & 3.3 & 1.6 \\
\hline 19 & Glyptothorax naziri & 9.3 & 7.5 & 8.2 & 6.2 & 1.5 & 0.2 & 1.8 & 1.3 \\
\hline 20 & Oreochromis niloticus & 10.9 & 8.3 & - & 7.1 & 3.1 & 0.9 & 3.2 & 1.5 \\
\hline 21 & Mastacembelus armatus & 32 & 28 & - & 29 & 2.8 & 0.4 & 2.4 & 2.1 \\
\hline
\end{tabular}




\section{Results of water quality parameters}

The investigated physico-chemical parameters of the water include water temperature, $\mathrm{pH}$, electrical conductivity, salinity, total hardness, total alkalinity, calcium hardness, magnesium hardness, total suspended solids, total dissolved solids and free $\mathrm{CO}_{2}$. All the parameters of the water of the river tochi are fall in the optimum range. The recorded mean values of water quality parameters are shown in the following table 4.

Table 4. Average values of different water quality parameters of river Tochi

\begin{tabular}{|c|c|c|c|c|c|c|c|c|}
\hline Parameters & July & Aug & Sep & Oct & Nov & Dec & Mean & S.D \\
\hline Air Temp $\left({ }^{\circ} \mathrm{C}\right)$ & 41 & 32 & 30 & 23 & 21 & 17 & 27.33 & 8.73 \\
\hline Water Temp $\left({ }^{\circ} \mathrm{C}\right)$ & 34 & 25 & 21 & 15 & 13 & 11 & 19.83 & 8.68 \\
\hline $\mathrm{pH}$ & 6.9 & 7.1 & 7.2 & 7.1 & 7.35 & 6.8 & 7.07 & 0.20 \\
\hline $\mathrm{E} . \mathrm{C}(\mu \mathrm{s} / \mathrm{cm})$ & 399 & 495 & 450 & 500 & 493 & 520 & 476.17 & 44.19 \\
\hline Salinity $(\mathrm{ppt})$ & 0.27 & 0.31 & 0.25 & 0.33 & 0.33 & 0.36 & 0.30 & 0.04 \\
\hline $\mathrm{T} . \mathrm{H}(\mathrm{mg} / \mathrm{L})$ & 121 & 129 & 125 & 122 & 130 & 139 & 127.67 & 6.62 \\
\hline $\mathrm{Ca} . \mathrm{H}(\mathrm{mg} / \mathrm{L})$ & 81 & 78 & 80 & 84 & 89 & 92 & 84 & 5.48 \\
\hline $\mathrm{Mg} . \mathrm{H}(\mathrm{mg} / \mathrm{L})$ & 39 & 41 & 45 & 38 & 41 & 47 & 41.83 & 3.48 \\
\hline $\mathrm{TSS}(\mathrm{mg} / \mathrm{L})$ & 175 & 154 & 180 & 124 & 175 & 150 & 159.67 & 21.36 \\
\hline $\mathrm{TDS}(\mathrm{mg} / \mathrm{L})$ & 370 & 410 & 394 & 400 & 435 & 412 & 403.5 & 21.59 \\
\hline Free CO $2(\mathrm{mg} / \mathrm{L})$ & 18 & 16 & 12 & 11 & 17 & 16 & 15 & 2.82 \\
\hline T. A $(\mathrm{mg} / \mathrm{L})$ & 78 & 74 & 80 & 89 & 80 & 81 & 80.33 & 4.92 \\
\hline
\end{tabular}

\section{Discussion}

This study was aimed to determine the fish fauna of river Tochi along with water quality at district North Waziristan. Shahjehan and Khan [11] reported fourteen species from River Tochi (Gambilla) at District Lakki Marwat K. P. (Pakistan). Their reported species were Salmostoma punjabensis, Barilius vagra, Puntius sophore, Mastacembelus armatus, Puntius ticto, Mystus bleekeri, Wallago attu, Glyptothrax punjabensis, Tor macrolepis, Aspidoparia morar and Channa punctatus.

As for as the present study is concerned, 21 species are reported from River Tochi. Likewise the previous record, the catch of this study is also dominated by family Cyprinidae and among the total 21 species, 13 species belong to family Cyprinidae, 3 to family Nemacheilidae, one to family Channidae, Siluridae, Sisoridae, Cichilidae and Mastacembelidae each.

Species like Barilius vagra, Puntius sophore, Mastacembelus armatus and Aspidoparia morar were also reported by Shahjehan and Khan [11]. Besides this all the species were not reported from river tochi earlier but are reported from different water bodies of adjoining areas (water bodies of district Bannu).

Mirza et al. [17], studied fish fauna River Kurram which flows at the side of river tochi in district bannu. They report 51 Species of fish from River Kurram. Among these most of the species are in common with fauna of river tochi i-e Barilius modestus, Barilius vagra, Barilius pakistanicus, Puntius sophore, Puntius conchonius, Gara gotyla, Crossocheilus diplocheilus, Aspidoparia morar, Cyprinion watsoni, Cyprinus carpio, Cirrhinus mrigala, Labeo rohita, Schistura prashari, Channa gachua, Ompok pabda and Mastacembelus armatus.

\section{Conclusion}

Among the reported species, 12 species are the new record from this river which are also recorded from different tributaries rivers and water bodies of the area. All water quality parameters results also fall in standard range and are suitable for fish life.

\section{Authors' contributions}

Conceived and designed the experiments: HJU Rehman \& MN Khabir, Performed the 
experiments: MN Khabir \& HJU Rehman, Analyzed the data: Z Hassan, Contributed materials/ analysis/tools: I Khan, M Kamal \& A Sohail, Wrote the paper: MN Khabir.

\section{References}

1. Shinde SE, Pathan TS, Bhandare RY \& Sonawane DL (2009). Ichthyofaunal diversity of Harsool savangi Dam, District Aurangabad India. World $J$ of Fish and Marine Sci 1(3): 141-143.

2. Nelson JS (2006). Fishes of the world. $4^{\text {th }}$ edition. John Wiley \& Sons, New York.

3. Ali SS \& Narejo NT (2009). Fundamentals of Ichthyology. Ist edition. Department of Freshwater Biology and Fisheries University of Sindh, Jamshoro (Pakistan).

4. Rafique M \& Khan NH (2012). Distributation of significant freshwater fishes of Pakistan. Pak J of Zool 32(4): 321-332.

5. Khan AM, Shakir HA, Khan MN, Abid M \& Mirza M R (2008). Ichthyofaunal survey of some freshwater reservoirs in Panjab, Pakistan.

6. Ali SS (1999). Freshwater Fisheries Biology, First edition, Naseem book depot shahrae Quaid e Azam, Hyderabad, Sindh.

7. Thirumala S, Kiran BR \& Kantaraj GS (2011). Fish diversity in relation to physicchemical characteristics of Bhadara reservoir of Karantak, India. Adv in Appl Sci Res 2(5): 34-47.

8. Nagabhushan CM \& Hosetti, BB (2001). Diversity of fishes in relation to physico- chemical characters of Tungabhadra reservoir, Hospet. Post Graduate Department of Zoology, Kuvempu University, India.

9. Mirza ZS, Mirza MR, Mirza MA \& Sulehria AQ (2011) Ichthyofaunal diversity of river Jhelum, Pakistan. Biol 57(1): 23-32.

10. Nawaz MK (2010). Pakistan mineral development corporation- FATA-DC Peshawar.

11. Shahjehan IA \& Shah I (2001). Ichthyofaunal diversity of river gambilla Lakki Marwat, PUTAJ.

12. Rahman AU (2003). Irrigation System in KP: Past, Present and Future Scenario. Peshawar Uni Teach Assoc J 10: 13-24.

13. University of the Punjab. Department of Zoology (1931). Fauna of Lahore. Punjab University, Lahore.

14. Mirza MR \& Sandhu IA (2007). Fishes of Punjab, Pakistan. Polymer publications, Rahat Market Urdu Bazar, Lahore.

15. Jayaram KC (2006). Catfishes of India. Narendera publishing house, New Delhi, India.

16. Jayaram KC (1999). The freshwater fishes of the Indian region. Narendra Publishing House: New Delhi, India.

17. Mirza MR, Javed MN \& Ali I (2008). Fish and Fisheries of Kurram in Pakistan. Biol (Pak) 54(2): 131-137. 